\title{
Spontaneous nontraumatic epidermoid cyst of the clitoris: a rare case report
}

\author{
Arun Nayak, Meenal Sarmalkar*, Madhuri Mehendale, Shrutika Shah
}

\begin{abstract}
Department of Obstetrics and Gynecology, Lokmanya Tilak Municipal Medical College \& General Hospital, Sion, Mumbai, Maharashtra, India
\end{abstract}

Received: 24 September 2015

Accepted: 31 October 2015

\section{*Correspondence:}

Dr. Meenal S. Sarmalkar,

E-mail: meenal.sarmalkar@gmail.com

Copyright: (C) the author(s), publisher and licensee Medip Academy. This is an open-access article distributed under the terms of the Creative Commons Attribution Non-Commercial License, which permits unrestricted non-commercial use, distribution, and reproduction in any medium, provided the original work is properly cited.

\begin{abstract}
Epidermoid cysts are slow growing, intradermal or subcutaneous tumors with a wall composed of true epidermis. They are rarely seen in the clitoral region but when found; they are commonly seen following female genital mutilation. Spontaneous onset clitoral epidermoid cysts have been scarcely reported .We report a rare case of a large spontaneous nontraumatic epidermoid cyst of clitoris in a 22 year old nulliparous female. This presentation mimicked clitoromegaly but was diagnosed to be a large epidermoid cyst after excision.
\end{abstract}

Keywords: Epidermoid cyst, Spontaneous, Nontraumatic, Clitoral cyst, Clitoromegaly

\section{INTRODUCTION}

Epidermoid cysts are slow growing intradermal or subcutaneous tumours lined with true epidermis arising from invagination of keratinizing squamous epithelium within the dermis. ${ }^{1}$ They are commonly found over the face, scalp, neck and trunk and rarely localized on the clitoris and labia. Clitoral cysts are very rare but when found are mostly associated with female genital mutilation/circumcision or trauma. ${ }^{2-4}$ We hereby report a case of epidermoid cyst of the clitoris which was spontaneous and nontraumatic in onset.

\section{CASE REPORT}

A 22 year-old unmarried girl attended the outpatient Department of Obstetrics and Gynecology with a history of swelling over genital region since 3 years. Swelling increased in size during first 4-5 months and then remained static during next two and half years. There was no history of increase in the size of the swelling on straining or lifting heavy weights. There were no abnormal bowel or bladder symptoms. She did not give any history of genital surgery or trauma at that site. She had no complaints of pain in lower abdomen, abnormal discharge per vaginum and menstrual abnormality.

On local examination there was a firm cystic swelling measuring $10 \times 6 \mathrm{~cm}$ in size arising from clitoral region covering the labia major deviated slightly towards the left side (Figure 1). On palpation the swelling was non reducible, non-fluctuant and mobile from side to side. There was no impulse on coughing in the swelling. Her general and systemic examinations were unremarkable.

Her routine blood investigations were normal. Ultrasonography of local site was suggestive of $10 \times 5 \mathrm{~cm}$ hyper echoic homogenous lesion arising in midline from vulva suggestive of dermoid cyst or lipoma. Patient was planned for surgical excision of the cyst under spinal anaesthesia. Complete excision of cyst was accomplished along with clitoral reconstruction (Figure 2). Special care was taken to preserve the blood supply of clitoris. Gross specimen was greyish white. Cut section showed mucoid material with smooth inner wall. Histopathology 


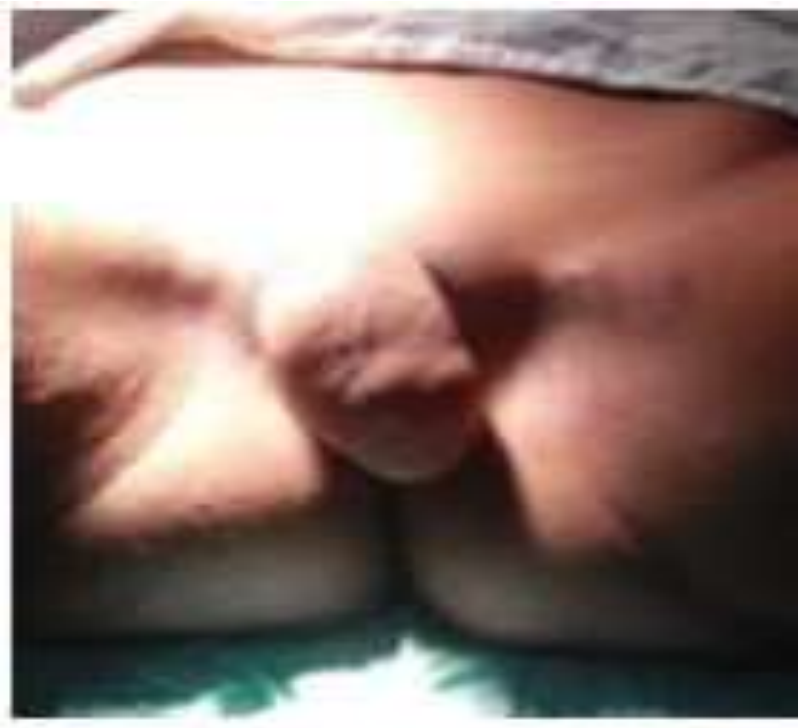

Figure 1: Cystic swelling in the clitoral region.

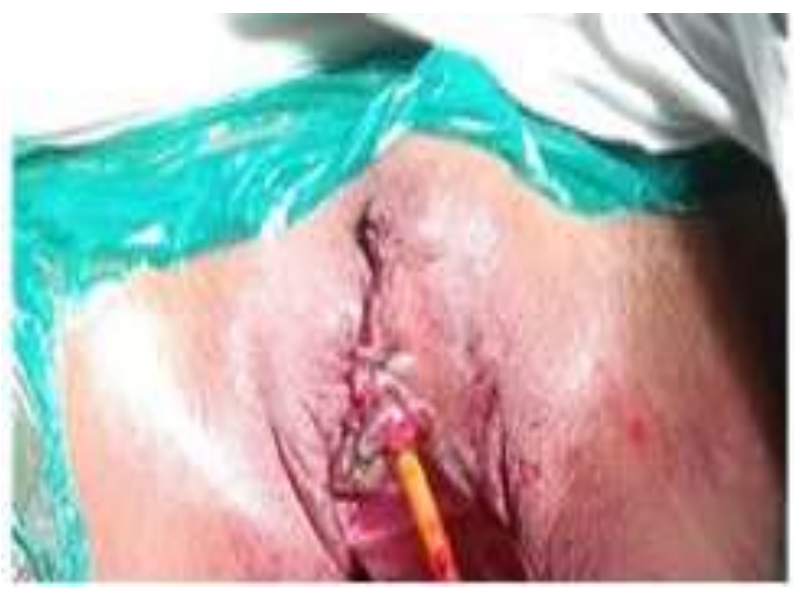

Figure 2: Post operative picture after excision of cyst with clitoral reconstruction.

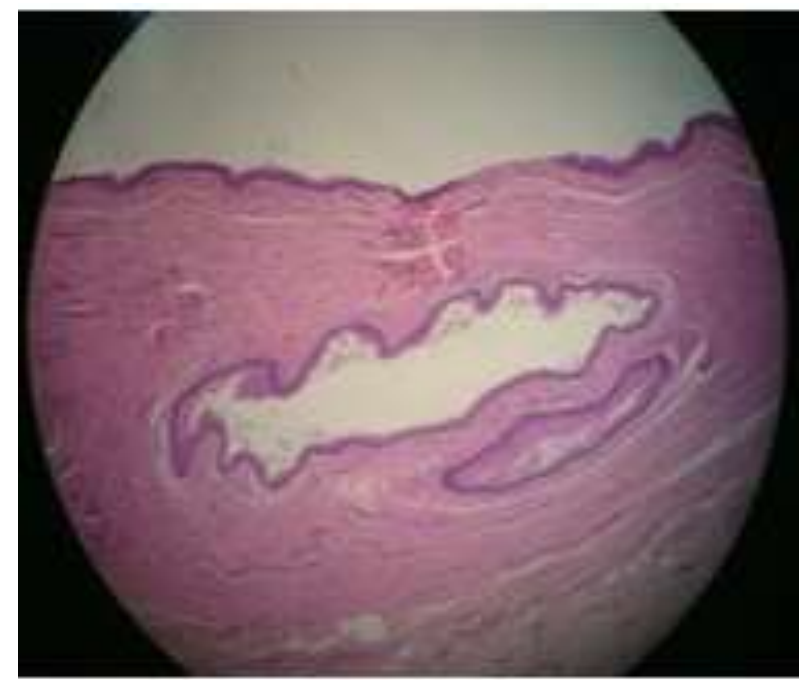

Figure 3: Histopathological findings of clitoral cyst: cyst wall lined by stratified squamous epithelium. confirmed the diagnosis of epidermoid cyst of clitoris which was lined by stratified squamous epithelium. Cyst showed desquamated keratinocytes with cyst wall composed of fibrocollagen (Figure 3). Patient was discharged on day 4 of surgery. Her postoperative recovery period was uneventful. On follow up visits there were no signs of recurrence.

\section{DISCUSSION}

Female external genitalia may have a multitude of cysts. Such cysts can be vaginal (hymenal), paraurethral or clitoral. ${ }^{5}$ Clitoral cysts are most infrequent of these. Clitoral cysts present clinically as a painless swelling gradually increasing in size. A soft, mobile, nontender mass in the clitoral region in the absence of any virilization sign is the typical physical finding. ${ }^{6-8}$ Clitoral enlargement due to hormonal causes or disorders of sexual differentiation is symmetrical and uniform. Epidermoid clitoral cyst is found to be one of the nonhormonal causes of acquired clitoromegaly. ${ }^{9}$

Epidermoid cysts are slow-growing, intradermal or subcutaneous tumors lined with true epidermis, arising from invagination of keratinizing squamous epithelium within the dermis. ${ }^{1}$ They are commonly found on the face, scalp, neck, and trunk. However the external genitalia can also be involved in the form of clitoral, labial, or scrotal implantation. When they involve the clitoris, they are mostly induced by trauma, and rarely appear spontaneously.

Epidermoid cysts of the clitoris are seen commonly after type I genital mutilation or female circumcision performed in some ethnic communities in Africa and West Asia. ${ }^{2-4}$ Only one case of clitoral epidermoid cyst following accidental trauma has been reported by Neslihan Celik et al. ${ }^{10}$

There have been only few reported cases of congenital or idiopathic epidermoid cysts of the clitoris without history of female genital mutilation. ${ }^{11-18}$ In our case, there was no history of female genital mutilation/trauma, and neither any history of oral contraceptive use or any other drug intake.

Careful evaluation of the patient with history, local examination of the cyst, and ultrasound of the cyst is needed for diagnosis of these cysts so as to prevent unnecessary hormonal investigations. Excision of cyst followed by clitoral reconstruction is the treatment.

\section{CONCLUSIONS}

Epidermoid clitoral cysts need to be considered in a case of clitoromegaly. Careful evaluation of the patient with history, local examination of the cyst, and ultrasound of the cyst is needed for diagnosis of these cysts so as to prevent unnecessary hormonal investigations. 
Funding: No funding sources

Conflict of interest: None declared

Ethical approval: Not Required

\section{REFERENCES}

1. Kirkham N. Tumors and cysts of the epidermis. In: Elder D.E., Elenitsas R., Johnson B.L., Murphy Jr G.F., editors. Lever's Histopathology of the Skin. 9th ed. Lippincott Williams \& Wilkins; Philadelphia: 2005;805-66.

2. Hanly MG, Ojeda VJ.Epidermal inclusion cysts of the clitoris as a complication of female circumcision and pharaonic infibulations. Central African Journal of Medicine.1995;41(1):22-24.

3. Adekunle AO, Fakokunde FA, Odukogbe AA, Fawole AO. Female genital mutilation-post circumcision vulval complications in Nigerians. J Obstet Gynaecol. 1999;19:632-5.

4. Rouzi AA, Sindi O, Radhan B, Ba'aqeel. Epidermal clitoral inclusion cyst after type I female genital mutilation. Am J Obstet Gynecol. 2001;185(3):56971.

5. Merlob P, Bahari C, Liban E, Reisner SH. Cysts of the female external genitalia in the newborn infant. Am J Obstet Gynecol. 1978;132:607-10.

6. Rizk DE, Mohammed KH, Joshi SU, Al- Shabani AY, Bossmar TR. A large clitoral epidermoid inclusion cyst first presenting in adulthood following childhood circumcision. J Obstet Gynaecol 2007;27:446-8.

7. Yoong WC, Shakya R, Sanders BT, Lind J. Clitoral inclusion cyst: a complication of type I female genital mutilation. J Obstet Gynaecol. 2004;24:98-9.

8. Çetinkurşun S, Narci A, Sahin O, Özkaraca E. Epidermoid cyst causing clitoromegaly in a child. Int J Gynaecol Obstet. 2009;105:64.
9. Linck D, Hayes MF. Clitoral cyst as a cause of ambiguous genitalia. Obstet Gynecol. 2002;99:9636.

10. Neslihan Ç, Şule Y, Şafak G, İbrahim K. Clitoral epidermoid cyst secondary to blunt trauma in a 9year-old child The Turkish Journal of Pediatrics 01 . 2011;53(1):108-10.

11. Anderson-Mueller BE, Laudenschlager MD, Hansen KA. Epidermoid cyst of the clitoris: an unusual cause of clitoromegaly in a patient without history of previous female circumcision J Pediatr Adolesc Gynecol. 2009;22(5):130-2.

12. Aggarwal SK, Manchanda V, and Pant N.Epidermoid cyst of clitoris mimicking clitoromegaly Indian Assoc Pediatr Surg. 2010;15(1):23-4.

13. Lambert B. Epidermoid cyst of the clitoris: a case report J Low Genit Tract Dis. 2011 Apr; 15(2):161-2.

14. Ekanath L, Rajasekaran A. A rare case of epidermoid cyst of clitoris. IJCRR. 2013;5(23): 10.

15. Al-Ojaimi EH, Abdulla MM. Giant epidermoid inclusion cyst of the clitoris mimicking clitoromegaly. J Low Genit Tract Dis. 2013;17(1):58-60.

16. Saha M. Epidermoid cyst of the clitoris: A rare cause of clitoromegaly. APSP J Case Rep. 2013;4(3):51.

17. Bhuria V, Malhotra V, Nanda S, Chauhan M, Goel B. Epidermoid Cyst of the Clitoris: An Unusual Case Journal of Gynecologic Surgery. 2014;30(1):61-3.

18. Schober MS, Hendrickson BW, Alpert SA. A Spontaneous clitoral hood epidermal inclusion cyst mimicking clitoromegaly in a pediatric patient.Urology. 2014;84(1):206-8.

Cite this article as: Nayak A, Sarmalkar M, Mehendale M, Shah S. Spontaneous nontraumatic epidermoid cyst of the clitoris: a rare case report. Int J Reprod Contracept Obstet Gynecol 2015;4:2081-3. 